\title{
Zájem o pohybové aktivity u studentů medicíny Univerzity Karlovy
}

\section{The interest in physical activities in medical students of Charles University Prague}

\author{
Jan Gajdošík, Jiř́i Baláš \\ Fakulta tělesné výchovy a sportu Univerzity Karlovy v Praze
}

\section{Abstrakt:}

Cílem práce bylo posoudit zájem o pohybové aktivity studentů prvnich ročníků na 2. a 3. lékařské fakultě (LF) UK. Dotazníkové šetrení bylo prováděno na souboru 407 studentů, kdy 182 studentů bylo z 2. LF UK a 225 studentĩ z 3. LF UK

Studenti obou fakult (2. a 3. LF) sportují nejčastěji do dvou hodin týdně (37\%, respektive $38 \%)$ a dvě až čtyři hodiny týdně (38\% respektive $34 \%$ ). 14,5\% studentů se věnuje sportu závodně, 4,6\% studenti̊ se nevěnuje pohybovým aktivitám vůbec. Cyklistice se ze zkoumaného souboru věnuje 111 studentů, plavání 98 studentů, běhání 63 studentů, volejbalu 62, sjezdovému lyžování 47 studentů, fitness aktivitám a turistice 40 studentů. Zájem studentů o zapojení do pohybových aktivit se profiluje jak u tradičních aktivit jako plavání, volejbal, fitness aktivity, cyklistika, tenis, zdravotni tělesná výchova, tak rovněž u ,nových “ aktivit jako sportovní lezení, squash, plážový volejbal, in-line bruslení, nordic walking, slackline, golf, florbal. Ukazuje se, že zařazení „nových“ atraktivních pohybových aktivit do vysokoškolské nabidky tělovýchovných kateder a ústavů může zvýšit zájem o tělesnou výchovu studentů.

\section{Abstract:}

The aim of the study was to assess the interest in physical activities in first year students of second (LF 2) and third (LF 3) medical faculty of Charles University. The sample of 407 students took part in the survey where 182 students were from LF 2 and 225 from LF 3. Students of both faculties (LF 2 and LF 3) practice a sport less than 2 hours per week (37\%, respective $38 \%$ ) and 2-4 hours (38\% respective $34 \%)$. There are $14.5 \%$ of students who regularly compete in a sport discipline and $4.6 \%$ of students do not practice any physical activity at all. Cycling is practised by 111, swimming by 98, running by 63, volleyball by 62, skiing by 47, fitness and ,turistika“ by 40 students. Interest in participating in physical activities is focused among traditional activities like swimming, volleyball, fitness, tennis, cycling, health oriented physical education and among ,,new" activities like sport climbing, squash, beach volleyball,in-line skating, nordic walking, slackline, golf, floorball. It was showed that including ,new"physical activities in curriculum may enhance the interest of students in physical education.

Klíčová slova: vysokoškolský sport, pohybové aktivity, tělesná výchova

Keywords: university sport, physical activities, physical education

\section{ÚVOD}

Pohybový režim dospělých je jednoznačně ovlivněn mírou pohybové aktivity v dětství (Cheung and Richmond 1995). V současné době můžeme konstatovat pokles realizované pravidelné pohybové aktivity v průběhu ontogeneze, především však u mládeže (Frömel et al., 2007; Moravec et al., 1996). Tento jev souvisí $\mathrm{s}$ výchovou v rodinách a ve školách, s nevhodnými podmínkami, s nedostatečnou osobní zkušeností a neinformovaností dětí o pohybových aktivitách (Lawson, 1995). Inaktivita je rovněž spojována se sledováním televize či časem stráveným u počítače (Sigmund et al., 2003; Sigmundová et al., 2005). Velmi výrazný pokles objemu pohybových aktivit je zejména u spontánně provozovaných pohybových činností (Riddoch, C.J., Boreham, 1995; Bunc et al., 2001).

Stejný trend jako u mládeže zaznamenáváme u dospělé populace, kdy s věkem dále klesá pravidelná 
pohybová aktivita mužů i žen a zvyšuje se počet neaktivních jedinců. Jansa, Kocourek a Votruba (2005) shledali 7,8 \% mužů a 9,4 \% žen ve věku 18-30 let bez jakýchkoli pohybových aktivit a po 61. roku již 12,9 \% mužů a 28,6 \% žen. Za jedno ze zlomových období můžeme považovat přechod ze studií do zaměstnání a počátek dospělosti. V období rané dospělosti se stále širší populace věnuje př́ípravě k budoucímu povolání na vysoké škole. Vysoká škola tedy může hrát významnou roli v utváření názoru na pohybovou aktivitu a sport.

Sport je s vysokoškolským prostředím českých zemí spjat více než sto let. Na začátku bylo velké přesvědčení a úsilí dr. Františka Smotlachy podporované kladným postojem k pohybovým aktivitám vysokoškolské mládeže (Smotlacha, 1921; Smotlacha, 1925; Smotlacha, 1934). Přestože se měnily podmínky, ve kterých byl vysokoškolský sport provozován, nezměnila se základní premisa k životaschopnosti tohoto fenoménu. Je jím potřeba aktivního pohybu, potřeba setkávání se a sdružování se, potřeba aktivního odpočinku a relaxace (Bělohlávek, 2010; Waic, 2011). Akademický sport je zajištován katedrami a ústavy tělesné výchovy. Na mnoha školách již tato pracoviště neobhájily svou existenci. Aby tělesná výchova nevymizela z programů akademického vzdělání, musí reflektovat současné zájmy studentů a nabídnout přitažlivé pohybové aktivity. Ze studie Valjenta (2010) na Českém vysokém učení technickém v Praze vyplývá, že u studentů jsou během celého studia velmi oblíbené aktivity jako kondiční posilování a plavání. Ve vyšších ročnících stoupá zájem o turistiku, lezení na umělé stěně, bowling, squash, lukostřelbu, kanoistiku. Pokles zájmu je patrný u softbalu, hokeje, basketbalu, volejbalu, florbalu, fotbalu, tedy především u sportovních her. Naší otázkou bylo, zda tyto výsledky budou platné i u studentů lékařských oborů, jejichž absolventi by měli působit v oblasti primární a sekundární prevence. Cílem práce bylo posoudit zájem o pohybové aktivity u studentů 2. a 3. lékařské fakulty Univerzity Karlovy v Praze.

\section{METODIKA}

\section{Výzkumný soubor}

Soubor, na kterém byl proveden výzkum, byl tvořen studenty nastupujícího ročníku 2. a 3. lékařské fakulty, kteří se zúčastnili tradičního vstupního soustředění v Dobronicích u Bechyně. Byli zde př́itomni studenti magisterského i bakalářského studia. Celkový počet studentů, kterým byl dotazník rozdán a kteří jej vrátili vyplněný je 407. Z 2. lékařské fakulty bylo př́tomno dotazování 182 studentů, z toho 134 studentů oboru všeobecné lékařství, 16 studentů oboru fyzioterapie a 32 studentů oboru všeobecná sestra. Z 3. lékařské fakulty bylo dotazování prítomno 225 studentů, z toho 174 studentů oboru všeobecné lékařství, 9 studentů oboru fyzioterapie, 25 studentů všeobecná sestra, 11 studentů veřejné zdravotnictví a 6 studentů dentální hygiena.

\section{Dotazníkové šetř̌ení}

Studentům byl rozdán dotazník v rámci jedné z přednášek asistentů Ústavu tělesné výchovy. Instrukce k jeho vyplnění jim byly podány slovně. Během vyplňování dotazníku byli asistenti neustále přítomni, schopni tak odpovídat na jakékoliv dotazy související s otázkami dotazníku a jejich zodpovězení. Na vyplnění dotazníku měli respondenti 30 minut, po té jej odevzdali vyučujícím. Díky tomu, že dotazníky byly rozdány a vybírány v průběhu výuky, byla návratnost dotazníků 100\%. Srozumitelnost dotazníku byla opakovaně ověřena v předešlých letech za stejných podmínek a srovnatelném počtu respondentů. $\mathrm{V}$ otázce o pravidelných pohybových aktivitách vypisovali studenti konkrétní sporty sami, nejednalo se o výběr z předloženého seznamu. V otázce, o které aktivity by měli studenti zájem v rámci nabídky tělesné výchovy, byl předložen seznam 19 aktivit: aerobik (zahrnující různé formy aerobiku v tělocvičně i v bazénu), balanční techniky (slackline a cvičení na balančních pomůckách), basketbal, plážový volejbal, cyklistika, golf, fitness aktivity (různé formy posilování), florbal, fotbal, in-line bruslení, kanoistika, nordic walking, plavání, softbal, sportovní lezení, squash, tenis, volejbal, zdravotní TV. Tento výběr byl dán personálními a materiálními možnostmi katedry TV, zahrnoval jak tradiční tak „nové“" pohybové aktivity.

\section{Vyhodnocení výsledků}

Výsledky byly zpracovány na základě četností odpovědí v jednotlivých otázkách pro obě fakulty zvlášt'. Četnosti byly vyjádřeny jak v absolutních tak v relativních číslech. Výsledky jsou prezentovány tabelárně nebo v sloupcových grafech. K veškerým výpočtům a grafickému zpracování byl použit Microsoft Excel 2010. 


\section{VÝSLEDKY}

Sportu na závodní úrovni se věnovalo v době dotazování 59 z celkového počtu 407 dotazovaných studentů. Nejvíce zastoupenými sportovními odvětvími v této položce jsou aerobik a volejbal, následuje plavání, fotbal, basketbal a orientační běh (graf 1 ).

Graf 1: Závodni sporty provozované studenty 2. lékařské (LF 2) a 3. lékařské fakulty (LF 3) Univerzity Karlovy

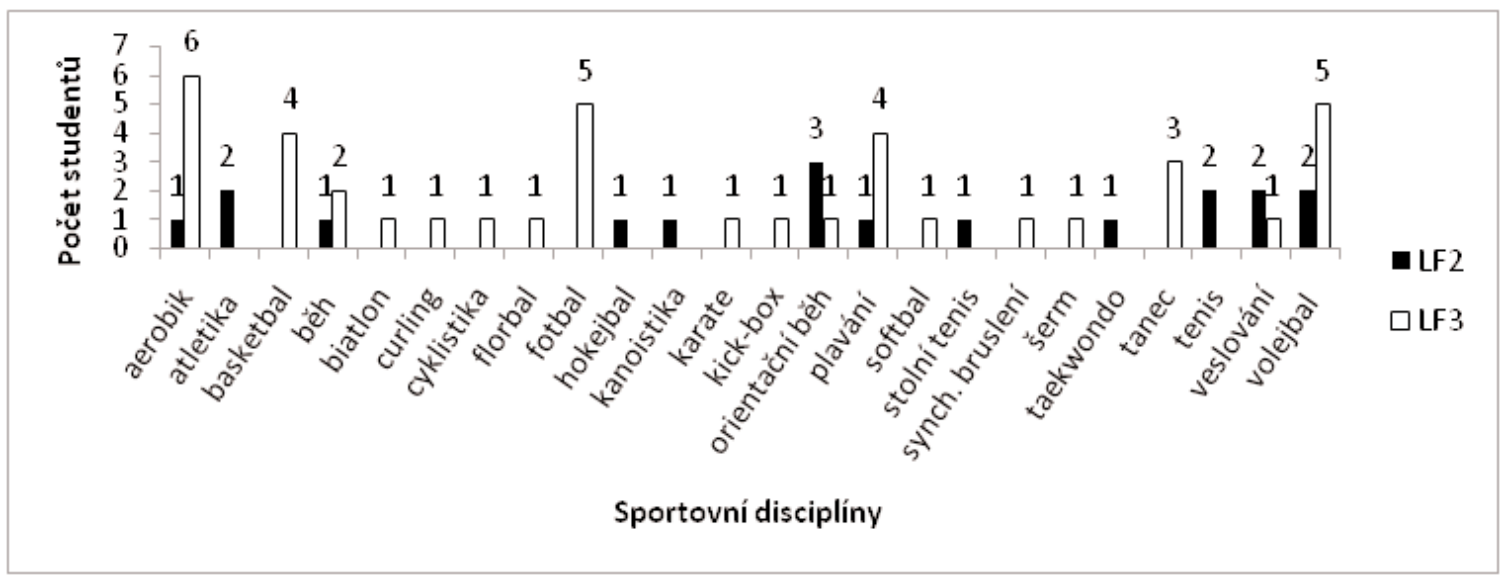

Tabulka 1 dokumentuje profil studentů v rámci jejich zájmové a volnočasové pohybové aktivity. Studenti mohli uvést více aktivit, kterým se věnují na rekreační úrovni. Jsou zde zastoupeny jak aktivity individuální, tak kolektivní, provozované v př́rodním prostředí i v hale. Velkému zájmu (40 osob a více) se mezi studenty těší cyklistika, plavání, běh, volejbal, sjezdové lyžování, fitness aktivity a turistika. Šedesát studentů uvedlo, že se na rekreační úrovni pohybovým aktivitám věnují, ale už neuvedli jakým. Devatenáct studentů, tedy 4,6 \% z celkového počtu dotázaných, se nevěnují sportu ani rekreačně. 
Tabulka 1: Rekreačni pohybové aktivity provozované studenty 2. lékařské a 3. lékařské fakulty

\section{Univerzity Karlovy}

\begin{tabular}{|c|c|c|}
\hline Sportovní disciplíny & Studenti 2. LF & Studenti 3. LF \\
\hline aerobic & 5 & 10 \\
\hline aikido & 1 & 0 \\
\hline atletika & 4 & 2 \\
\hline badminton & 6 & 6 \\
\hline basketbal & 12 & 4 \\
\hline Plážový volejbal & 1 & 0 \\
\hline běh & 44 & 19 \\
\hline bez specializace & 22 & 38 \\
\hline běžecké lyžování & 10 & 4 \\
\hline bruslení & 2 & 2 \\
\hline cyklistika & 58 & 53 \\
\hline fitness & 21 & 19 \\
\hline florbal & 7 & 8 \\
\hline fotbal & 17 & 11 \\
\hline golf & 4 & 1 \\
\hline gymnastika & 2 & 1 \\
\hline hokej & 3 & 3 \\
\hline in-line & 14 & 14 \\
\hline jízda na koni & 5 & 2 \\
\hline jóga & 0 & 4 \\
\hline kanoistika & 1 & 4 \\
\hline karate & 1 & 0 \\
\hline sportovní lezení & 4 & 12 \\
\hline lukostřelba & 1 & 0 \\
\hline plavání & 54 & 44 \\
\hline sjezdové lyžování & 30 & 17 \\
\hline skialpinismus & 2 & 3 \\
\hline snowboarding & 9 & 3 \\
\hline squash & 9 & 11 \\
\hline stolní tenis & 7 & 8 \\
\hline tanec & 17 & 16 \\
\hline tenis & 23 & 14 \\
\hline turistika & 20 & 20 \\
\hline volejbal & 37 & 25 \\
\hline zumba & 1 & 7 \\
\hline nesportuje & 6 & 13 \\
\hline
\end{tabular}

Jednu až dvě hodiny za týden věnuje pohybovým aktivitám 153 studentů, o jednu až dvě hodiny více 143 studentů. Více jak čtyři hodiny stráví sportováním 111 studentů, tedy jedna čtvrtina dotázaných (graf 2). V jednotlivých bodech otázky jsou velmi podobné četnosti odpovědí u obou fakult, maximální rozdíly jsou 3,0 \%. 
Graf 2: Čas věnovaný pohybovým aktivitám studenty 2. lékařské (LF 2) a 3. lékařské (LF 3) fakulty Univerzity Karlovy

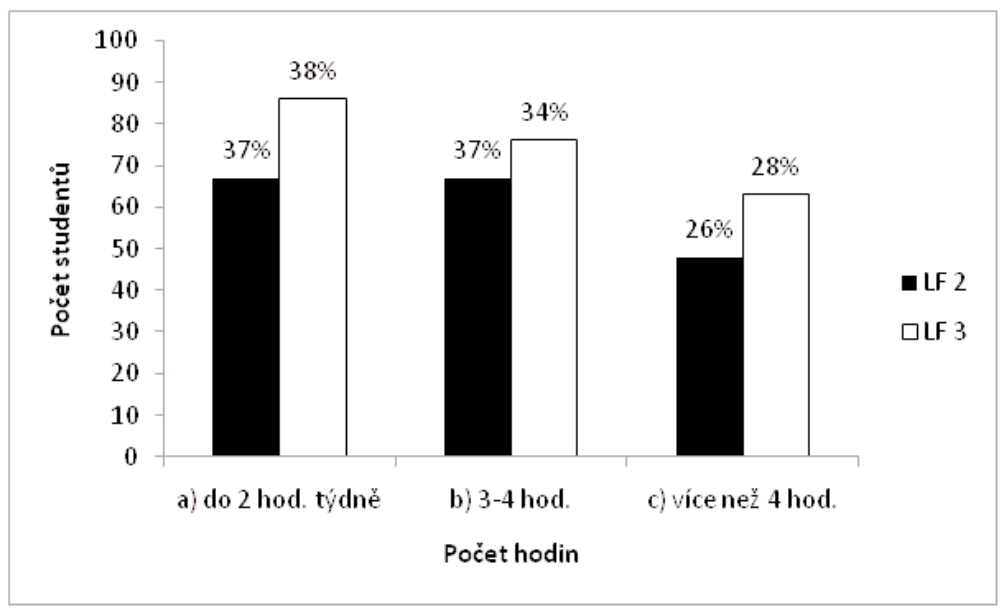

Nejvíce studentů, polovina dotázaných, se kloní k názoru, že by tělesná výchova měla být povinně volitelná, 173 studentů je pro povinnou formu tělesné výchovy. Pouze 27 studentů si myslí, že by sport neměl být součástí jejich vysokoškolského studia (graf 3). Povinnou tělesnou výchovu by uvítalo 58 \% studentů 2. LF UK, ale pouze $30 \%$ studentů 3 . LF UK. U povinně volitelné tělesné výchovy je tomu naopak, tuto variantu by volilo $39,0 \%$ studentů 2 . LF UK oproti $60 \%$ studentů 3. LF UK. Nepovinnou tělesnou výchovu by volilo pouze $3 \%$ studentů 2. LF UK, ale už $10 \%$ studentů 3. LF UK (graf 3).

Graf 3: Zájem o různé formy výuky na 2. lékařské ( $L F$ 2) a 3. lékařské (LF 3) fakultě Univerzity Karlovy

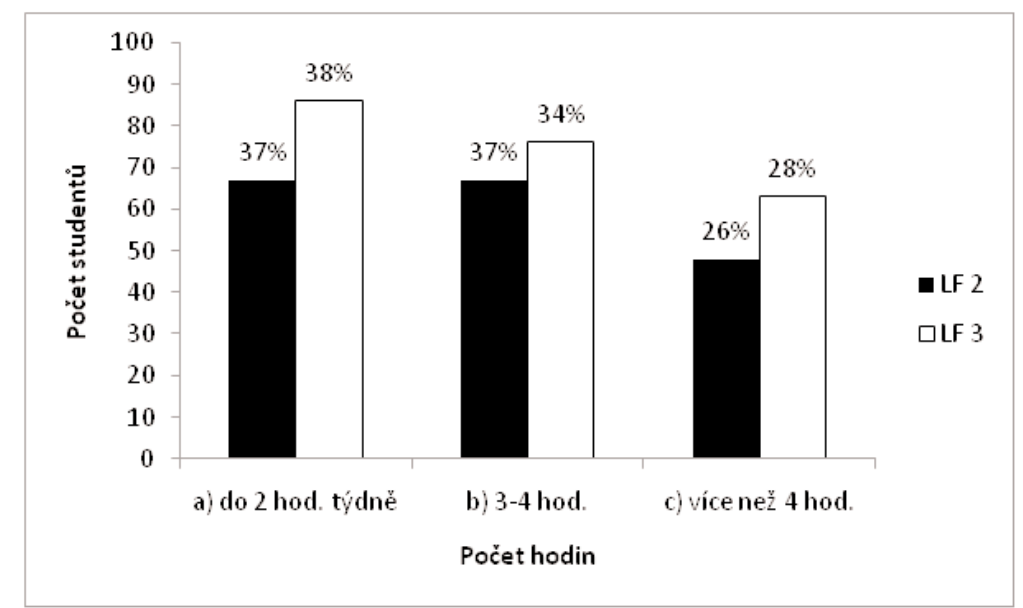

Nejvíce studentů (225) by uvítalo, pokud by výuka TV byla zaměřena na způsoby a principy začleňování sportovních pohybových aktivit do režimu běžného dne. O seznámení se s pohybovými aktivitami v primární a sekundární prevenci v rámci hodin TV projevilo zájem 194 studentů. O zlepšování své fyzické kondice by nejraději usilovalo 120 studentů a o zlepšení ve vybrané sportovní disciplíně 63 dotazovaných (graf 4). 
Graf 4: Zájem o zaměreni výuky TV u studentů 2. lékařské ( $L F$ 2) a 3. lékařské fakulty (LF 3) Univerzity Karlovy (PA - pohybové aktivity, PAPP - pohybové aktivity v primární prevenci, PASP - pohybové aktivity v sekundární prevenci)

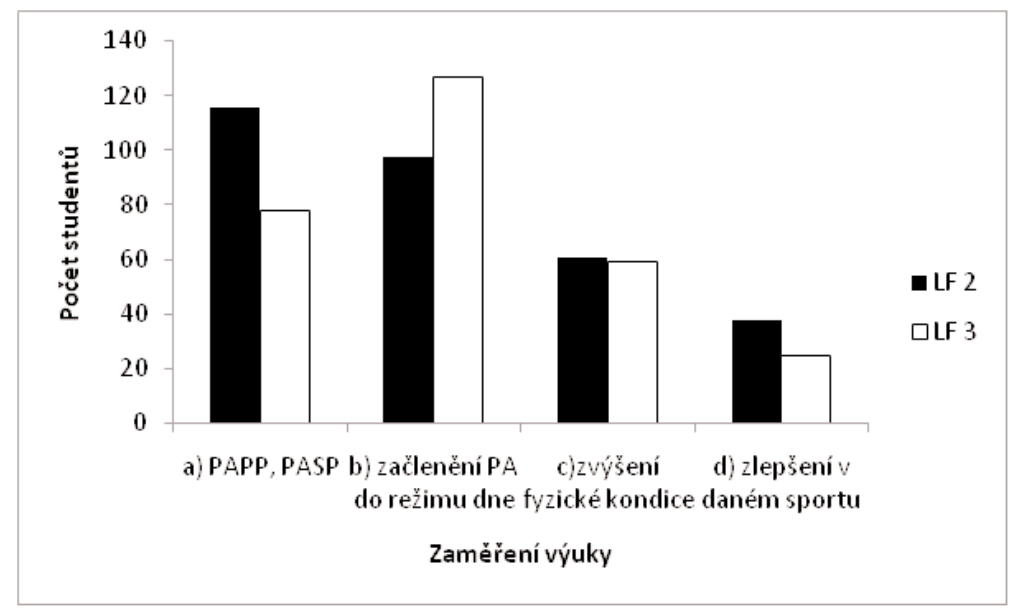

Dále jsme zjišt’ovali, o jaké sportovní zaměření by měli studenti v rámci výuky TV zájem. Byly jim nabídnuty jednak sportovní aktivity, které se běžně v rozvrhu objevují a jednak ty sporty, o jejichž začlenění do rozvrhu bylo uvažováno. Největší zájem byl projeven o plavání (204 studentů), fitness (149), volejbal (135), zdravotní TV (127), aerobic (125), tenis (121), sportovní lezení (110), cyklistiku (98) a in-line bruslení (97).

Graf 5: Zájem o různé sportovní disciplíny v rámci výuky TV u studentů 2. lékařské (LF 2) a 3. lékařské fakulty (LF 3) Univerzity Karlovy

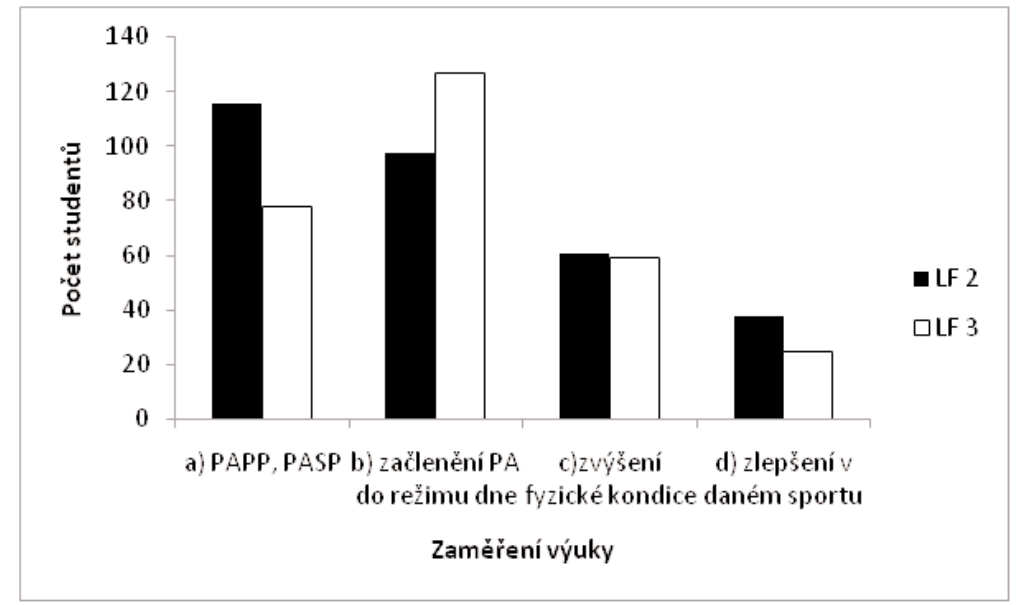

\section{DISKUSE}

Na 2. a 3. LF se hlásí $14,5 \%$ studentů, kteří se věnují sportu na závodní úrovni. Na opačném konci bychom našli 4,6 \% studentů, kteří se nevěnují sportu vůbec. Toto číslo je menší, než shledali Teplý (1983) nebo Jansa, Kocourek, Votruba (2005), kteří uvádějí, že v dospělé české populaci se sportu nevěnuje vůbec 7,0 - 8,0 \% lidí. Studie provedená na Fakultě managementu v Jindřichově Hradci (Král, Vislocká, Voldán, 2003) uvádí, že 86,0 \% studentů provozuje alespoň jednou týdně nějakou pohybovou aktivitu. Čtrnáct procent se tedy nevěnuje žádné aktivitě. Zda je větší počet pohybově neaktivních studentů managementu oproti medikům dán zaměřením, podmínkami nebo chybou dotazování může být jen spekulací. Autoři studie uvádějí, že se studenti managementu věnují sportu průměrně třikrát v týdnu. Nejvíce dotázaných $(75,0 \%)$ uvedlo, že se sportu věnují individuálně, bez odborného dozoru či pomoci, následuje sportování v rámci univerzitního sportu $(63,0 \%)$, fitness-center využívá $30,0 \%$.

V naší studii s nejvíce studentů věnuje sportu do 2 hodin týdně, méně studentů 2 až 4 hodiny za týden. Více času pohybovými aktivitami tráví jedna čtvrtina dotázaných. Tento stav by mohl souviset s faktem, že lidé 
$\mathrm{v}$ tomto věku věnují sportu tolik času, kolik mu byli zvyklí věnovat na základních a středních školách v rámci výuky. Sami mimo školní výuku sportují minimálně (Sigmundová et al., 2005). U nastupujících studentů 3. LF UK je ve srovnání se studenty 2. LF UK dvojnásobný počet nesportujících studentů. O povinnou tělesnou výchovu projevilo zájem $58 \%$ studentů 2 . LF UK, ale pouze $30 \%$ studentů 3. LF UK. Studenti 3. LF UK si ve větší míře myslí, že by výuka měla být povinně volitelná $(60 \%)$, studenti 2 . LF jsou této formě výuky nakloněni z $39 \%$. Na 3. LF UK je podle dotazníku také více studentů (10 \%), kteří nemají o tělesnou výchovu zájem, na 2. LF UK jsou to pouze $3 \%$.

Studenti mají zájem se v rámci školní TV seznámit s co největším množstvím pohybových aktivit, studenti 2. LF UK by tuto formu tělesné výchovy zvolili z $96 \%$, studenti 3. LF UK z $88 \%$. Zájem studenti projevili také o problematiku související se začleněním pohybových aktivit do režimu dne, stejně tak mají zájem dozvědět se něco o principech, jak předcházet pomocí sportu různým nemocem, př́padně, jaké sporty jsou vhodné v rámci sekundární prevence.

Mezi nejčastěji uváděné aktivity sportujících studentů se objevují tradiční individuální disciplíny jako cyklistika, plavání, běh, sjezdové lyžování, fitness aktivity a turistika. Ze sportovních her to byl pouze volejbal. Z odpovědí studentů je patrná inklinace k individuálně provozovaným sportovním aktivitám, což koresponduje s výzkumy Valjenta (2010), který deklaroval pokles zájmu vysokoškolákủ u softbalu, hokeje, basketbalu, volejbalu, florbalu, fotbalu, tedy především u sportovních her.

Z nabídky pohybových aktivit byl největší zájem studentů o tradiční plavání, volejbal, fitness aktivity, cyklistiku, tenis, zdravotní tělesnou výchovu a o „nové“ aktivity jako sportovní lezení, squash, plážový volejbal, in-line bruslení, nordic walking, slackline, golf, florbal. Opět jsou naše výsledky v souladu s Valjentem (2010), který ve vyšších ročnících konstatoval stoupající zájem o lezení na umělé stěně, bowling, squash, lukostřelbu, kanoistiku, turistiku. Tyto „nové“ aktivity většinou nevyžadují velký počet osob (spoluhráčů) a lze je jednodušeji zakomponovat do individuálního volnočasového programu. Malina a kol. (2004) upozorňuje, že většina pohybových aktivit je asociována s týmovými sporty. A zatímco málo dospělých je zapojeno do týmových pohybových aktivit, dovednosti nabyté v mládí nejsou v pozdějším věku využity. Z dlouhodobého hlediska je vhodné rozšírít pohybový rejstř́k o co nejvíce dovedností, které mohou být praktikovány po celou délku života (Twisk, 2001). S touto myšlenkou se celkem ztotožňují i studenti medicíny, kteří v tělesné výchově chtějí poznat využití pohybových aktivit v primární a sekundární prevenci a v pohybových režimech. Výkonnostní hledisko je pro ně nejméně zajímavé.

\section{ZÁVĚRY}

Studenti 2. a 3. lékařské fakulty UK sportují nejčastěji dvě až čtyři hodiny týdně. 14,5 \% studentů se věnuje sportu závodně, 4,6 \% studentů se nevěnuje pohybovým aktivitám vůbec. K nejčastěji pěstovaným aktivitám patří cyklistika, plavání, běh, volejbal, sjezdové lyžování, fitness aktivity a turistika. Zájem studentů o zapojení do pohybových aktivit se ukazuje jak u tradičních aktivit jako plavání, volejbal, fitness aktivity, cyklistika, tenis, zdravotní tělesná výchova, tak rovněž u „nových“ aktivit jako sportovní lezení, squash, plážový volejbal, in-line bruslení, nordic walking, slackline, golf, florbal. Ukazuje se, že zařazení „nových“ atraktivních pohybových aktivit do vysokoškolské nabídky tělovýchovných kateder a ústavů může zvýšit zájem o tělesnou výchovu studentů.

\section{Literatura}

Bělohlávek, J. (2010). 100 let českého vysokoškolského sportu. Praha: Olympia.

Bunc, V., Horčic, J., Cingálek, R., \& Moravcová, J. (2001). Tělesná zdatnost českých dětí a mládeže. In Tilinger, P., Rychtecký, A., \& Perič, T. Sport v České republice na začátku nového tisíciletí. (1. vydání, Vol. 2, 101 - 105). Praha: Univerzita Karlova v Praze.

Frömel, K., Chmelík, F., Bláha, L., Feltová, D., Fojtík, I., Horák, S., Klobouk, T. et al. (2007). Pohybová aktivita české mládeže: koreláty intenzivní pohybové aktivity. Česká kinantropologie, 11, 49-55.

Cheung, L.W.Y., \& Richmond, J.B. (1995). Child health, nutrition, and physical activity. Champaign: Human Kinetics. 
Jansa, P., Kocourek, J., \& Votruba, J. Sport a pohybové aktivity v životním stylu české dospělé populace (18 - 61 a více let). In Jansa, P., Kocourek, J., Votruba, J., \& Dašková, B. Sport a pohybové aktivity v životě české populace. (1. vydání, 70 - 82). Praha: Univerzita Karlova v Praze.

Král, P., Vislocká, M., \& Voldán, P. (2003) Postavení pohybových a sportovních aktivit v životě studentů malé regionálni fakulty. In Vindušková, J., \& Chrudimský, J. Pohybové aktivity jako prostředek ovlivňování člověka. (1. vydání, 110 - 114). Praha: Univerzita Karlova v Praze.

Lawson, H (1995). School reform, families, and health in the emergent national agenda for economic and social improvement: implications, Quest, 45, 8-33.

Malina, R.M., Bouchard, C., \& Bar-Or, O. (2004). Growth, maturation and physical activity. Champaign: Human Kinetics.

Moravec, R., Kampmiller, T., Sedláček, J., et al. (1996). EUROFIT Telesný rozvoj a pohybová výkonnost’ školskej populácie na Slovensku. Bratislava: Slovenská vedecká spoločnost’ pre telesnú výchovu a šport.

Riddoch, C. J., \& Boreham, C. A. (1995) The health-related physical aktivity of children, Sports Med., 19, 86-102.

Sigmund, E., Frömel, K., Dlugopolská, D., Groffik, D., \& Novosad, J. (2003). Nástin trendu ve vývoji pohybové aktivity dětí a mládeže s jejich vzrůstajícím věkem. In. Sborník příspěvků mezinárodního semináre Pedagogické kinantropologie. (1. vydání, 45 - 50). Ostrava: Pedagogická fakulta.

Sigmundová, D., Frömel, K., \& Sigmund, E. (2005). Semilongitudinální monitorování pohybové aktivity adolescentů: výsledky po čtyřech letech. In Sbornik príspěvků mezinárodního semináře Pedagogick kinantropologie. (1. vydání, 117 - 129). Ostrava: Pedagogická fakulta.

Smotlacha, F. (1921). Přednášky a stati z tělesné výchovy. Rokycany.

Smotlacha, F. (1925) Kniha o tělesné výchově na vysokých školách v ČSR. Praha.

Smotlacha, F. (1934). Kniha o vysokoškolském sportu. Praha.

Teplý, Z. (1983). Pohybový režim 15-29letých občanů ČSR. Praha: Metodické oddělení ČÚV ČSTV a Výzkumný ústav tělovýchovný FTVS UK v Praze.

Twisk, J.W.R. (2001). Physical activity guidelines for children and adolescents: a critical review. Sports Med., 31, 617-627.

Valjent, Z. (2010). Aktivní životni styl vysokoškoláků. Praha: České vysoké učení technické v Praze.

Waic, M. (2011). Zrození českého akademického sportu a František Smotlacha. Česká kinantropologie, 15, $49-56$. 